\title{
WOOD COLOR VARIATION IN UNDRIED AND KILN-DRIED PLANTATION-GROWN LUMBER OF Vochysia guatemalensis
}

\author{
VARIACIÓN DEL COLOR DE LA MADERA ASERRADA EN \\ ESTADO VERDE Y SECA AL HORNO DE Vochysia guatemalensis \\ PROVENIENTE DE PLANTACIONES DE RÁPIDO CRECIMIENTO
}

\author{
Diana Aguilar-Tovar ${ }^{1}$, Róger Moya $^{2}$, Carolina Tenorio ${ }^{2}$
}

\begin{abstract}
Vochysia guatemalensis has been planted over large tropical areas to obtain lumber products. However, compared with naturally-grown material variations in wood color have been noted. In the current research, trees from two 8-year-old fast-grown plantations were sampled from different climatic conditions in order to identify the causes of color variation. The study evaluated the heartwood presence, grain pattern, distance from pith, height within the tree, and effect of drying schedules. The wood color was measured by CIEL*a*b* systems.

Wood color of Vochysia guatemalensis is a combination of different tonalities of lightness $\left(\mathrm{L}^{*}\right)$, redness $\left(\mathrm{a}^{*}\right)$, and yellowness $\left(\mathrm{b}^{*}\right)$, however, the lightness and yellowness components were the dominant tones. The color of heartwood and sapwood were different before and after drying. A negative relationship was found between $\mathrm{a}^{*}$ and $\mathrm{L}^{*}$, and $\mathrm{a}^{*}$ and $\mathrm{b}^{*}$ in the undried state, but no relationship was found between $\mathrm{L}^{*}$ and $\mathrm{b}^{*}$. The $\mathrm{L}^{*}$ index is only correlated with heartwood presence in undried wood. In dried wood, only a relationship between $\mathrm{a}^{*}$ and $\mathrm{L}^{*}$ is maintained, while other color parameters were affected by climate, drying schedule and heartwood presence, the $\mathrm{L}^{*}$ parameter being the most affected. The dried wood displays a lighter surface than the wood before drying. The variations in the dried wood suggest that it is useful to establish dried lots of lumber according to the drying schedule, source and presence of sapwood and heartwood.
\end{abstract}

Keywords: Fast growth plantations, tropical species, CIElab color systems, wood quality.

\section{RESUMEN}

La especie Vochysia guatemalensis ha sido plantada sobre largas áreas en regiones tropicales. Así mismo, han sido observadas grandes variaciones del color de su madera. En la investigación fueron muestreadas plantaciones de 8 años de edad en diferentes condiciones de clima con el fin de establecer las causes de variación de la madera. Fueron evaluadas la presencia de duramen, el patrón de aserrío, la distancia de la medula y el programa de secado. El color fue medido por el sistema CIELab.

\footnotetext{
${ }^{1}$ Universidad del Tolima, Facultad de Ingeniería Forestal, B. Santa Helena A.A. 546 - Ibagué, Colombia

${ }^{2}$ Instituto Tecnológico de Costa Rica, Escuela de Ingeniería Forestal, Apartado 159-7050, Cartago, Costa Rica.

Corresponding author: rmoya@itcr.ac.cr

Received: 14. 09. 2009. Accepted: 03.11. 2009.
} 
Fue encontrado que la madera de $V$. guatemalensis presenta una combinación de tonalidades de claros $\left(\mathrm{L}^{*}\right)$, rojos $\left(\mathrm{a}^{*}\right)$ y amarrillos $\left(\mathrm{b}^{*}\right)$, siendo los colores claros y amarrillos los tonos dominantes. El color del duramen y la albura fueron diferentes antes y después del secado. Una negativa correlación entre $a^{*} \mathrm{y} \mathrm{L}^{*}, \mathrm{y}^{*} \mathrm{y} \mathrm{b}^{*}$ fue encontrada, pero ninguna correlación fue observada entre $\mathrm{L}^{*} \mathrm{y} \mathrm{b}^{*}$. El índice $\mathrm{L}^{*}$ fue el único parámetro correlacionado con el duramen en madera verde. En la madera seca, solamente se mantuvo la relación a* y L*, mientras que los parámetros del color fueron afectados por el clima, programa de secado y duramen, siendo $L^{*}$ el más afectado. La madera seca presentó una superficie más clara que la madera antes del secado. Las variaciones en madera seca sugieren la conveniencia de establecer lotes de secado de acuerdo al programa de secado aplicado, procedencia y presencia de albura y duramen.

Palabras claves: Rápido crecimiento, especies tropicales, CIElab, calidad de madera.

\section{INTRODUCTION}

Vochysia guatemalensis, is the most important native species among fast-growth plantations in Costa Rica. It has high productivity, ability to be grown on abandoned areas, agroforestry and silvopastoral systems. These factors are promoting reforestation of the country with native species (Montagnini 2007, Calvo-Alvarado et al. 2007). However, lumber produced from thinnings and clear-cut trees of fast-growth plantations has been found to have major wood color variation (Moya et al. 2008).

Wood color is an important deciding wood characteristic for many uses, such as furniture and decorative veneers and is considered to be an important attribute for marketing (Janin et al. 2001). Möttönen et al. (2002) noted that wood characteristics and uniformity of wood color played an important role in establishing lumber prices. Moya et al. (2009) mentioned that the color of sapwood is white and that of heartwood is light reddish in $V$. guatemalensis lumber, but they did not discuss wood color variation within or between boards, or its variation with others factors.

One of the most accurate and commonly used systems for measuring wood color is the CIELab color system. According to HUNTER LAB (1995), the CIELab color system estimates the wood color in three coordinates: $\mathrm{L}^{*}$ for lightness, represents the position on the black-white axis $(\mathrm{L}=0$ for black, $\mathrm{L}=100$ for white); $\mathrm{a}^{*}$ for chrome value, defines the position on the red-green axis ( +100 values for red shades,-100 values for green shades); and $b^{*}$ for chroma value, defines the position of the yellow-blue axis ( +100 values for yellow shades, -100 values for blue shades).

Due to lack of information to explain the causes for the variations of wood color of $V$. guatemalensis lumber, this research examined wood color measured by CIE Lab color systems in relation to climatic conditions, position in stem height and distance from the pith, saw pattern (tangential and radial sawn), heartwood or sapwood presence, and kiln drying schedules. On the basis of this knowledge, we can explain wood color variation in dried wood and possibly improve lumber quality for marking

\section{METHODS AND MATERIAL}

\section{Geographic position and characteristics of plantation}

Trees from two 8-year-old fast-grown plantations were chosen to study the influence of drying on lumber characteristics. One plantation was located in a Northern region of Costa Rica, with a tropical 
dry climate, where typical conditions are temperatures from 21 and $31{ }^{\circ} \mathrm{C}$, precipitation of $1620 \mathrm{~mm}$ per year, and a dry season extending from November to May. It was planted by Precious Woods S.A. (MACORI) Company. The second plantation was located in a tropical wet climate zone, with temperature from 20 to $25^{\circ} \mathrm{C}$, average precipitation of $2953 \mathrm{~mm}$, and with a short dry season, extending from February to March. It was planted by the Escuela de Agricultura de la Región del Trópico Húmedo (EARTH). The plantation characteristics are detailed in Table 1.

Table 1. Plantation characteristics of fast-growth plantation of $V$. guatemalensis

\begin{tabular}{|c|c|c|c|c|c|}
\hline Climatic condition & $\begin{array}{c}\text { Tree age } \\
(\text { years })\end{array}$ & $\begin{array}{c}\text { Plantation stocking } \\
(\mathrm{n} / \mathrm{ha})\end{array}$ & $\begin{array}{c}\text { Diameter breast } \\
(\mathrm{cm})\end{array}$ & Tree height $(\mathrm{m})$ & $\begin{array}{c}\text { Volume } \\
\left(\mathrm{m}^{3} / \mathrm{ha}\right)\end{array}$ \\
\hline Dry tropical & 8 & 464 & 26.0 & 18.5 & 215.3 \\
\hline Wet tropical & 8 & 486 & 26.3 & 17.8 & 212.3 \\
\hline
\end{tabular}

\section{Sampled trees}

Ten representative trees from each plantation were harvested as a second thinning of the test stands (Petit and Montagnini 2006). All harvested trees were comparable in average DBH, a straight bole, normal branching, and absence of pests or diseases. North orientation was marked on each tree prior to harvesting and then marked on each log. From each selected tree, two $2.5 \mathrm{~m}$ logs were obtained, one from the tree base (lower log) and the other from a 2.5 to $5.0 \mathrm{~m}$ height (upper log). Each log was end-coated to retard drying and reduce end splits. All logs were transported without delay to the sawmill of the Instituto Tecnológico de Costa Rica. Logs were sawn using a pattern designed to produce $25 \mathrm{~mm}$ thick boards with the saw patterns being those different orthotropic directions commonly used in Costa Rica to obtain wood for the furniture industry. The boards from the north-facing side of each log were separated from those facing to the south. An edger was used to remove the bark. Each board was properly identified by climatic condition, height, pith, location geographic position, and tree number. In total, from all of the logs 258 boards were obtained. However some boards were split for pith presence or fungal attack which meant only 247 boards were finally used in the study.

\section{Drying process and moisture content determination}

Ttwo kiln drying schedules were used to dry the lumber to $10 \% \mathrm{MC}$. " $\mathrm{A}$ " refers to schedule T2-D4 (Table 2) proposed by Boone et al. (1988), for wood from natural forest, and it was named "fast drying". The second schedule (Table 2) used higher equilibrium moisture contents in all drying steps. It was slower than T2-D4 schedule, and was named "slow-drying". Total drying times were 150 hours for the fast-drying schedule and 227 hours for the slow-drying one. 112 boards from the north-facing side of each log were used in fast-drying (FD) and 112 boards in slow drying (SD). Moisture content was determined before and after drying, following the ASTM D1442-92 (ASTM 2003) standard. 
Table 2. Kiln schedules used for drying Vochysia guatemalensis

\begin{tabular}{|c|c|c|c|c|c|c|}
\hline \multirow{2}{*}{ Step } & \multicolumn{3}{|c|}{ Fast-drying* } & \multicolumn{3}{c|}{ Slow-drying } \\
\cline { 2 - 7 } & $\begin{array}{c}\text { Td } \\
{ }^{\circ} \mathrm{C}\end{array}$ & $\begin{array}{c}\text { EMC } \\
\%\end{array}$ & $\begin{array}{c}\text { RH } \\
\%\end{array}$ & $\begin{array}{c}\text { Td } \\
{ }^{\circ} \mathrm{C}\end{array}$ & $\begin{array}{c}\text { EMC } \\
\%\end{array}$ & $\begin{array}{c}\text { RH } \\
\%\end{array}$ \\
\hline \multirow{2}{*}{ Heating } & 35 & 14.8 & - & 35 & 18.0 & - \\
\hline & 38 & 14.3 & 50 & 38 & 17.0 & 82 \\
& 38 & 11.9 & 45 & 38 & 15.0 & 79 \\
\hline \multirow{5}{*}{ Drying } & 38 & 11.9 & 35 & 38 & 13.0 & 74 \\
& 43 & 10.5 & 30 & 44 & 11.0 & 69 \\
& 44 & 7.6 & 30 & 44 & 9.0 & 55 \\
& 49 & 5.5 & 25 & 49 & 7.0 & 42 \\
\hline Equalization & 55 & 4.0 & 20 & 55 & 5.0 & 31 \\
\hline Conditioning & 66 & 3.2 & 15 & 66 & 3.2 & 21 \\
\hline Cooling & 66 & 3.2 & 12 & 66 & 3.2 & 21 \\
\hline & 66 & 3.2 & 12 & 66 & 3.2 & 21 \\
\hline
\end{tabular}

*Dryings schedules from Boone et al. (1988).

Legend: $\mathrm{Td}=$ Dry-bulb temperature, $\mathrm{EMC}=$ equilibrium moisture content, $\mathrm{RH}=$ relative humidity.

\section{Wood color determination}

Colour was measured using a portable Miniscan XE plus colorimeter (HUNTER LAB) in each board before and after drying. The colorimeter was re-calibrated each time before use, with a white standard probe supplied by HUNTER LAB. The reflectance spectra were recorded using the standardized CIEL*a*b* chromaticity system as a function of wavelength (BYK-Gardner 2004). The measurement was within the visible range of $400-700 \mathrm{~nm}$ at intervals of $10 \mathrm{~nm}$ with a measuring aperture of $11 \mathrm{~mm}$. For reflection readings, the observer component was set at an angle of $90^{\circ}$ with the surface of the specimen. The standard illuminant D65 (corresponding to daylight at $6500 \mathrm{~K}$ ) was used as the color space measuring and computing parameter. Two measurements along the boards were taken, and average values were obtained for $L^{*}, a^{*}$ and $b^{*}$. Each measurement was identified as being taken from either heartwood or sapwood.

\section{Statistical Analysis}

Before analysis of variance (ANOVA) and other statistical analyses, it was necessary to confirm the assumptions of normality and homogeneity of variance. The UNIVARIATE procedure of SAS System for Windows release 8.1 (SAS Institute Inc., Cary, N.C.) was used to test the assumptions for analysis of variance. Pearson correlation coefficients were computed to analyze the relationships between color coordinates and tree height, climatic type, grain pattern, distance to pith, and heartwood percentage in wood color analysis. Regression analysis was used to determine the relationships of color coordinates $\left(\mathrm{L}^{*} \mathrm{a}^{*} \mathrm{~b}^{*}\right)$ before and after drying, for sapwood and heartwood. SAS (SAS Institute Inc.) and STATISTICA 6.0 (Statsoft Inc.) software were used for the statistical computations. 


\section{RESULTS AND DISCUSSION}

\section{Wood color difference between sapwood and heartwood}

The average colorimetry results in sapwood and heartwood of $V$. guatemalensis in CIEL*a*b* color systems are shown in Table 3. All color parameters are positive, meaning that wood color of this species is a combination of different tonalities of lightness, redness, and yellowness. However, the lightness and yellowness components are the highest proportions in both types of wood. The color of heartwood and sapwood are different before and after drying. Sapwood color averages 73.5 in L*, 6.3 in $\mathrm{a}^{*}$ and 68.1 in $\mathrm{b}^{*}$ and heartwood color averages $68.1,5.8$ and 22.1 , respectively before drying. ANOVA analysis shows lightness and yellowish parameters of sapwood are higher than in heartwood, but no difference was found in redness color parameters before drying. After drying, $L^{*}$ parameters averaged 70.9 in sapwood and 70.7 in heartwood, a* averaged 6.7 in heartwood and 5.8 in sapwood, and finally, $\mathrm{b}^{*}$ averaged 22.3 in heartwood and 20.6 in sapwood. Statistical analysis determined that $\mathrm{L}^{*}$ was not different between heartwood and sapwood, but the $a^{*}$ and $b^{*}$ parameters were significantly higher in heartwood. Gierlinger et al. (2004) mentioned that change in color between sapwood and heartwood is due to the synthesis and accumulation of extractives during heartwood formation. Heartwood color is in part due to oxidation and polymerization reactions that take place as wood ages.

On the other hand, the variations of wood color parameters (measured by coefficients of variance) were similar before and after drying (Table 3). Variation in the $\mathrm{a}^{*}$ parameter is the highest (over $23.8 \%$ ), and the smallest variation (minor than $8 \%$ ) occurred in $\mathrm{L}^{*}$ parameter, both in sapwood and heartwood before and after drying. The coefficients of variation of $b^{*}$ ranged from $7.8 \%$ to $15.3 \%$ (Table 3). The color of wood is related to the presence of extractives and the chemical composition of lignin in some species (Gierlinger et al. 2004). The variation in extractives content or composition produced by different soil properties or different growing conditions can explain wood color variation of heartwood and sapwood (Lui et al. 2005). For example, redness ( $\left.\mathrm{a}^{*}\right)$ and lightness ( $\mathrm{L}^{*}$ ) are correlated with extractive content, while yellowness is primarily related to the photochemistry of the major chemical components of wood, especially lignin (Gierlinger et al. 2004).

Moya et al. (2009) studied wood color of lumber from fast-growth plantation of $V$. guatemalensis and they mentioned that wood color is basically white for sapwood and light red or reddish for heartwood, according to the Musell Soil Color Charts (Mac Corporation 1994).Wood color measured with CIE L*a*b* color systems confirmed that high lightness $\left(\mathrm{L}^{*}\right)$ and yellowness $\left(\mathrm{b}^{*}\right)$ levels and low redness level ( $\left.\mathrm{a}^{*}\right)$ are typical of sapwood, and these parameters establish the white color in sapwood of $V$. guatemalensis. But a decrease in lightness and yellowness level increases reddish color of heartwood, before and after drying.

Table 3. Color parameters of $V$. guatemalensis before and after drying, measured with the CIEL*a*b* system.

\begin{tabular}{|c|c|c|c|c|}
\hline Wood & Conduction & $\begin{array}{c}\mathrm{L}^{*} \\
\text { (lightness) }\end{array}$ & $\begin{array}{c}\mathrm{a}^{*} \\
\text { (redness) }\end{array}$ & $\begin{array}{c}\mathrm{b}^{*} \\
\text { (yellowness) }\end{array}$ \\
\hline \multirow{2}{*}{$\begin{array}{c}\text { Sapwood } \\
(\mathrm{N}=165)\end{array}$} & Before & $\begin{array}{c}73.5 \\
(5.8) \text { and }(7.9)\end{array}$ & $\begin{array}{c}6.3 \\
(1.6) \text { and }(25.3)\end{array}$ & $\begin{array}{c}68.1 \\
(5.3) \text { and }(7.8)\end{array}$ \\
\cline { 2 - 5 } & After & $\begin{array}{c}70.9 \\
(5.7) \text { and }(8.0)\end{array}$ & $\begin{array}{c}5.8 \\
(1.6) \text { and }(27.3)\end{array}$ & $\begin{array}{c}20.6 \\
(2.6) \text { and (12.6) }\end{array}$ \\
\hline \multirow{2}{*}{$\begin{array}{c}\text { Heartwood } \\
(\mathrm{N}=60)\end{array}$} & Before & $\begin{array}{c}68.1 \\
(5.3) \text { and }(7.8)\end{array}$ & $\begin{array}{c}6.9 \\
(1.9) \text { and }(23.4)\end{array}$ & $\begin{array}{c}22.1 \\
(2.7) \text { and (12.6) }\end{array}$ \\
\cline { 2 - 5 } & After & $\begin{array}{c}70.7 \\
(4.5) \text { and (6.4) }\end{array}$ & $\begin{array}{c}6.7 \\
(1.5) \text { and }(23.8)\end{array}$ & $\begin{array}{c}22.3 \\
\text { and (3.0) }(15.3)\end{array}$ \\
\hline
\end{tabular}

Note: the values in parenthesis standard deviations and coefficients of variation respectively and $\mathrm{N}=$ samples numbers 


\section{Relation between wood color coordinates}

There is a negative relationship between $\mathrm{a}^{*}$ and $\mathrm{L}^{*}$ parameters in sapwood and heartwood, for both undried and dry lumber (Figure 1a and $1 \mathrm{~b}$ ). No significant relationship was found between $\mathrm{L}^{*}$ and $b^{*}$ in undried wood (Figure 1c), but a significant relationship between $a^{*}$ and $b^{*}$ (Figure 1e) in undried lumber was found but with a weak relations $\left(\mathrm{R}^{2}\right.$ between $10 \%$ and $\left.20 \%\right)$. These relationships are not found in dried wood (Figure 1d and 1f). These results suggest that when lightness ( $\mathrm{L}^{*}$ ) increases, redness decreases $\left(\mathrm{a}^{*}\right)$, and that other sources not considered in this study may influence the relation between $a^{*}$ and $b^{*}$, such as variation of quality or quantity of extractives (Keey 2005).

Nishino et al. (1998) and Moya and Berrocal (2009) measured the correlations between different color parameters of many tropical species from Guiana and Tectona grandis, respectively. They showed that only $\mathrm{L}^{*}$ and $\mathrm{a}^{*}$ parameters were correlated, but no relationship was established between $\mathrm{b}^{*}$ and $\mathrm{L}^{*}$, or between $\mathrm{a}^{*}$ and $\mathrm{b}^{*}$. Their results differed from the current results for $V$. guatemalensis. The results regarding a relationship between wood color parameters in Fagus sylvatica (Liu et al. 2005) agreed with the current results for undried condition, but not for dry lumber. It was found that the parameters of the CIEL*a*b* color system were significantly correlated ( $\mathrm{L}^{*}$ with $\mathrm{a}^{*}, \mathrm{~L}^{*}$ with $\mathrm{b}^{*}$, and $\mathrm{a}^{*}$ with $\left.\mathrm{b}^{*}\right)$. The relationships between color parameters varied within species, indicating that this relationships depends others factors, such extractives composition. Some extractives precursors of the wood color are located in some species, but they not presents in others species, affecting the relationships of wood color.
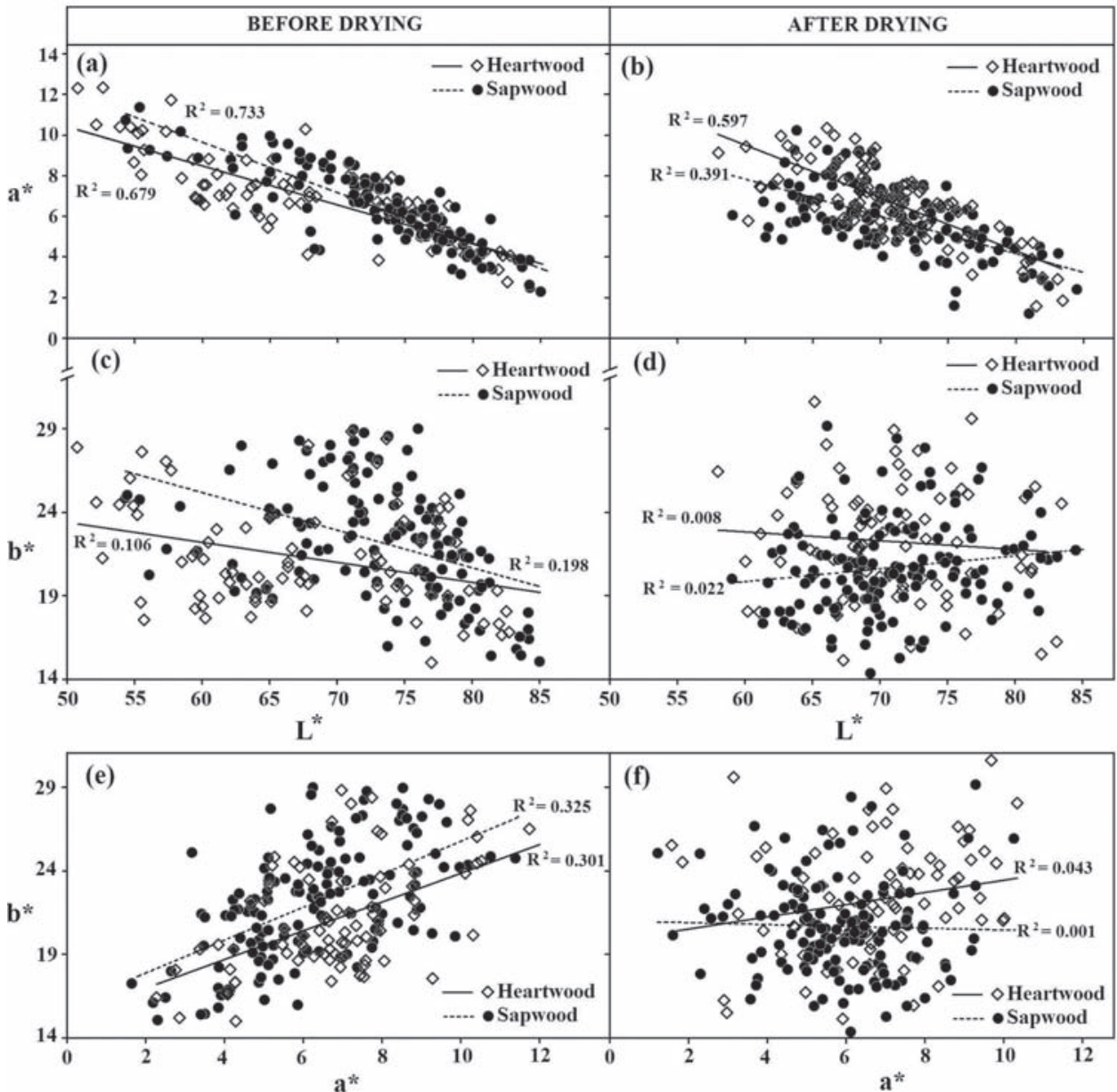

Figure 1. Relationships between wood color parameters lumber of Vochysia guatemalensis before and after drying. 


\section{Wood color difference before and after drying}

It was found that sapwood and heartwood lumber color were different before and after drying. All color parameters decreased slightly in sapwood but only $\mathrm{L}^{*}$ coordinates increased significantly after drying in heartwood (Figure 2). The $\triangle \mathrm{E}^{*}$ parameter, which measures color difference between two points in a Cartesian plane, was 7.7 and 8.3 in sapwood and heartwood, respectively. When, $\Delta \mathrm{E}^{*}$ is greater than 2, the human eye can detect wood color variation (Gonnet 1993). Therefore, there is a visually perceptible difference between before and after the drying process. According to these results, dry lumber with sapwood reaches a less pale yellow or less white than in a undried condition because lightness $\left(\mathrm{L}^{*}\right)$, redness $\left(\mathrm{a}^{*}\right)$ and yellowness index $\left(\mathrm{b}^{*}\right)$ decrease; but heartwood decreased its redness for decreasing redness parameters $\left(\mathrm{a}^{*}\right)$ and increasing yellowness parameters $\left(\mathrm{b}^{*}\right)$. Therefore, after drying there is a decrease in wood color difference between sapwood and heartwood.

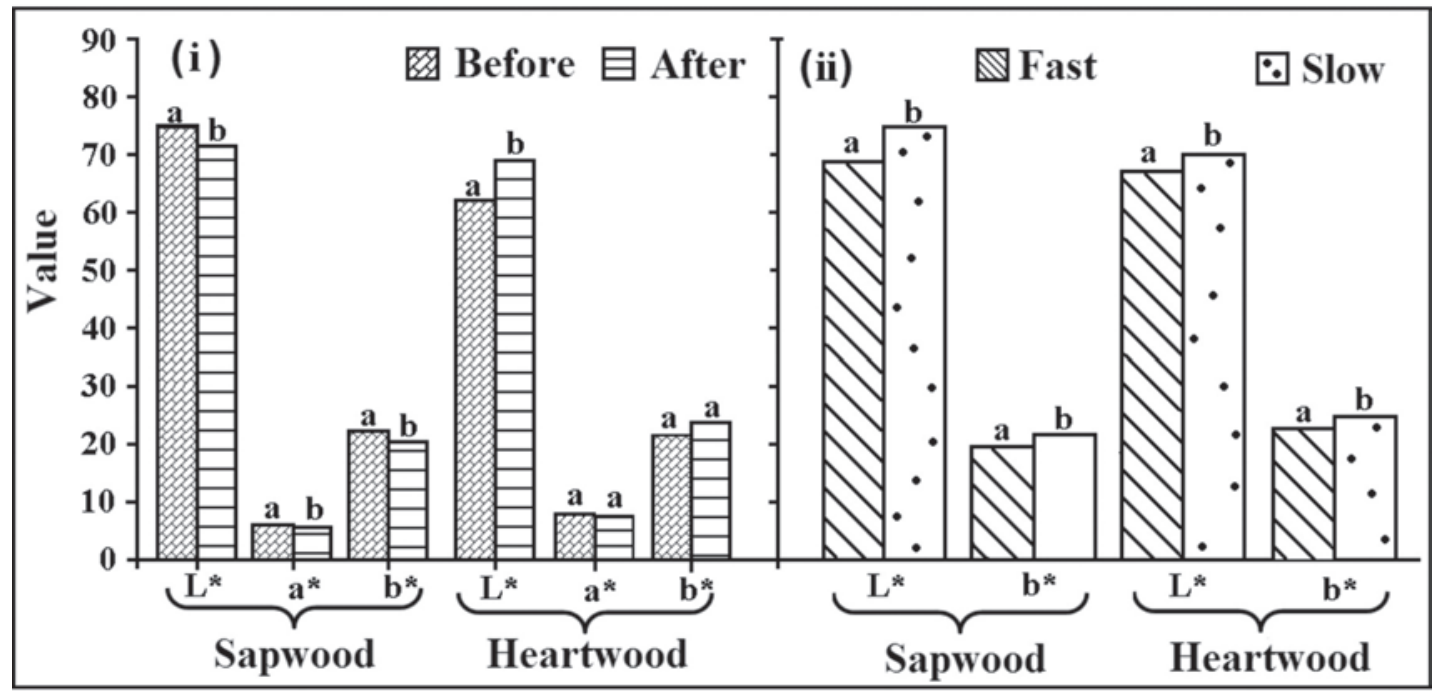

Figure 2. Variation of wood color parameters before and after drying (i), and as a result of different drying schedules in sapwood and heartwood (ii).

Keey (2005) mentioned that superficial changes in color of boards after drying are produced by water movement and movement of dissolved substances from the interior to the surface. Substances are dissolved in water, then water in the surface is evaporated and wood extractives are concentrated at or near the surface. Sugars of low-molecular weight and nitrogenous compounds such as proteins produce a reddish color. However, wood color change can occur only on surface areas in many species (Sundvist 2002).

\section{Sources of wood color variation}

The lightness index $\left(\mathrm{L}^{*}\right)$ was the only parameter of wood color affected statistically before drying. As was discussed previously, sapwood and heartwood color are different (Table 4). But other factors had a statistically significant affect on wood color parameters in dry lumber. The $\mathrm{L}^{*}$ parameter was negatively affected by heartwood presence, type of drying schedule, and variation in the final moisture content (Table 4). The a* parameter was also significantly affected by final moisture content (Table 4) and $b^{*}$ was affected by climate condition where the tree growing and by the type of drying schedule. 
According to these results, slow drying produces lower $\mathrm{L}^{*}$ and $\mathrm{a}^{*}$ values than fast drying (Figure $2 b$ ), thus resulting in grayer wood (increasing $\mathrm{L}^{*}$ and $\mathrm{b}^{*}$ parameters). On the other hand, boards from trees growing in dry sites in Costa Rica produce wood color with less yellow (increasing $b^{*}$ component) than wood from wet locations. Finally, ANOVA analysis showed that color difference from undried to after drying, as measured by $\Delta \mathrm{E}^{*}$ index, did not have any relationship with the variables studied (Table 4). This means that change of wood color (ie lightness) in lumber of $V$. guatemalensis will occurs when lumber is kiln dried, regardless of any condition of growing, drying schedule, or position from within the tree.

Table 4. Pearson correlation coefficient between wood color of $V$. guatemalensis before and after drying process.

\begin{tabular}{|l|c|c|c|c|c|c|}
\hline \multirow{2}{*}{ Source of variation } & \multicolumn{3}{|c|}{ Before drying } & \multicolumn{3}{c|}{ After drying } \\
\cline { 2 - 7 } & $\mathbf{L}^{*}$ & $\mathbf{a}^{*}$ & $\mathbf{b}^{*}$ & $\mathbf{L}^{*}$ & $\mathbf{a}^{*}$ & $\mathbf{b}^{*}$ \\
\hline Climatic condition & 0.13 & 0.02 & 0.05 & -0.04 & -0.07 & $-0.36^{*}$ \\
\hline Part of tree & 0.16 & -0.11 & 0.02 & 0.12 & -0.22 & -0.06 \\
\hline Distance from pith & 0.14 & -0.09 & 0.14 & 0.07 & -0.16 & -0.06 \\
\hline Type of drying & 0.07 & 0.05 & -0.25 & $-0.45^{* *}$ & 0.24 & $-0.38^{* *}$ \\
\hline Grain pattern & -0.18 & 0.09 & -0.09 & 0.05 & 0.14 & 0.09 \\
\hline Heartwood presence & $-0.35^{*}$ & 0.19 & -0.12 & $-0.42^{* *}$ & 0.32 & $0.25^{*}$ \\
\hline MCi & -0.26 & 0.13 & -0.11 & -0.15 & 0.22 & 0.23 \\
\hline MCf & -0.14 & 0.15 & -0.24 & $-0.29^{*}$ & $0.29^{*}$ & -0.18 \\
\hline
\end{tabular}

Legend: * Statistically significant at $\alpha=0.05, * *$ Statistically significant at $\alpha=0.01$.

Wood color variation after drying in $V$. guatemalensis can be caused by migration of different color precursors, such as phenol extractives (Kreber and Haslett 1998). The intensity of this variation is influenced by dry bulb temperature, air velocity, and relative humidity inside the kiln (Stenudd 2004, Rappold and Smith 2004). We did not determined quality and quantity of extractives of surface of lumber of $V$. guatemalensis, however a determination can help to explain the wood color performance

\section{CONCLUSIONS}

Undried wood color of Vochysia guatemalensis is a combination of different tonalities of lightness, redness, and yellowness. However, the lightness and yellowness components are the most prevalent tones in both heartwood and sapwood. Dried lumber color in heartwood and sapwood is different than after drying. All color parameters were different after dryings, excepts in $a^{*}$ and $b^{*}$ parameters of heartwood.

There was a negative relationship between $\mathrm{a}^{*}$ and $\mathrm{L} *$ parameters in undried and dried lumber for both sapwood and heartwood, and now relationship was found between $\mathrm{L}^{*}$ and $\mathrm{b}^{*}$; but there was a relationship between $a^{*}$ and $b^{*}$ in undried lumber. However, these relationships are not found in kiln dried wood. These results suggest that an increase of lightness is associated with a decrease redness $\left(a^{*}\right)$, that other sources not considered in this study may influence the relation between $\mathrm{a}^{*}$ and $\mathrm{b}^{*}$. 
Lightness index $\left(\mathrm{L}^{*}\right)$ is only correlated with the presence of sapwood or heartwood in the undried condition, but other wood color parameters were not correlated with any other factors studied. After drying, the wood color varies according to the climate conditions where the tree grew, drying schedule applied, and the presence of heartwood. The $\mathrm{L}^{*}$ color parameter is the factor most affected. Drying in $V$. guatemalensis wood produces a lighter surface than before drying. Therefore, dry surface is lighter than undried surface. According with this results, the color in dried lumber will produced for its precedence, drying schedule or sapwood/heartwood, therefore we can established color class for different end-users.

\section{ACKNOWLEDGEMENTS}

The authors wish to thank Escuela de Agricultura de Trópico Húmedo (EARTH) and Maderas Preciosas de Costa Rica (MACORI) for raw materials and facilities for the study. We thank the Vicerrectoría de Investigación y Extensión at the Instituto Tecnológico de Costa Rica for financial support.

\section{REFERENCES}

American Society for Testing and Materials. 2003. Standard Test Methods for Direct Moisture Content Measurements of Wood and Wood-Base Materials ASTM D-1442-92 (Reproved 2003).

Boone, R.S.; Kozlik, C.J.; Bois, P.J.; Wengert, E.M. 1988. Dry kiln schedules for commercial woodstemperate and tropical. Gen. Tech. Rep. FPL-GTR-57. Department of Agriculture, Forest Service, Forest Products Laboratory. Madison, Wisconsin U.S.

Byk-Gardner L. 2004. CIE L*a*b* system. Color-guide 45/0 operating instructions, MD, USA.

Calvo-Alvarado, J.C.; Arias, D.; Ritcher, D.D. 2007. Early growth performance of native and introduced fast growing tree species in wet to sub-humid climates of the Southern region of Costa Rica. Forest Ecology Management 242: 227-235

Gierlinger, N.; Jacques, D.; Gradner, M.; Wimmer, R.; Schwanninger M.; Rozenberg, P.; Pâques L.E. 2004. Colour of larch heartwood and relationships to extractives and brown-rot decay resistance. Trees 18: 102-108

Gonnet, J.F. 1993. CIELab measurement, a precise communication in ower colour: an example with carnation (Dianthus caryophyllus) cultivars. Journal Horticulture Science 68: 499-510

Hunterlab, 1995. Use measurement of apparence. A welly-Interscience publication, Welly and Sond, New York.

Janin, G.; Goncalez, J.; Ananias, R.; Charrier, B.; Fernandes, G.; Dilem, A. 2001. Aesthetics appreciation of wood colour and patterns by colorimetry. Part 1. Colorimetry theory for the CIELab Sistem. Maderas. Ciencia y tecnología 3: 3-13 
Keey, R. 2005. Colour development on drying. Maderas. Ciencia y tecnología 7:3-16

Kreber, B.; Haslett, A.N. 1997. A study of some factors promoting kiln brown-stain formation in radiate pine. Holz als Rush Werk 55: 355-362

Liu, S.; Loup, C.; Gril, J.; Dumonceaud, O.; Thibaut, A.; Thibaut, B. 2005. Studies on European beech (Fagus sylvatica L.). Part 1: Variations of wood color parameters. Annals Forest Science 62: 625-632

Mac Corporation. 1994. Munsell soil color charts. Macbeth Division of Kollmorgen Instruments Corporation. New York, US.

Montagnini, F. 2007. Management for Sustainability and Restoration of Degraded Pastures in the Neotropics. In: Post-Agricultural Succession in the Neotropics. Ed. Wyster, R. Springer Verlag, New York

Möttönen, K.; Alvila, L.; Pakkanen, T. 2002. CIELab Measurements to determine the role of felling season, log storage and kiln drying on coloration of silver Birch wood. Scandinavian Journal Forest Research 17: 179-191

Moya, R., Leandro, L., Murillo, O. 2009. Wood characteristics of Terminalia amazonia, Vochysia guatemalensis and Hyeronima alchorneoides planted in Costa Rica. Bosque 30(2):78-87

Moya, R.; Berrocal, A. 2009. Wood colour variation in sapwood and heartwood of young trees of Tectona grandis and its relationship with plantation characteristics, site, and decay resistance. Annals Forest Science (accepted)

Moya, R.; Urueña, E.; Muñoz, F. 2008. Modulation of moisture content in conventional kiln of wood from fast-growing tropical species in plantation. CD. SWST, L. (ed). Proceedings SWST Annual Meeting. 10-12 de noviembre de 2008. Concepción - Chile.

Nishino, Y.; Janin, G.; Chanson, B.; Detienne, P.; Gril, J.; Thibaut, B. 1998. Colorimetry of wood specimens from French Guiana. Journal Wood Science 44:3-8

Petit, B.; Montagnini, F. 2006. Growth in pure and mixed plantations of tree species used in reforesting rural areas of the humid region of Costa Rica, Central America. Forest Ecology and Management 233: 338-343

Rappold, P.; Smith, W. 2004. An investigation of the relationships between harvest season, log age, and drying schedule on the coloration of hard maple lumber. Forest Products Journal 54: 178-184

Stenudd, S. 2004. Color response in silver birch during kiln-drying. Forest Products Journal 54(6): $31-36$

Sundqvist, B. 2002. Wood color control during kiln-drying. Forest Products Journal 52(2): 30-37 